\title{
PERKEMBANGAN HASIL TANGKAPAN IKAN PELAGIS KE.CIL DI SEKITAR LAUT JAWA
}

\author{
Achmad Zamroni dan Suwarso \\ Peneliti pada Balai Riset Perikanan Laut, Muara Baru-Jakarta \\ Teregistrasi I tanggal: 18 Nopember 2008; Diterima setelah perbaikan tanggal: 13 Pebruari 2009: \\ Disetujui terbit tanggal: 16 juni 2009
}

\section{ABSTRAK}

Pukat cincin merupakan alat tangkap utama untuk perikanan pelagis kecil serta mempunyai peranan penting di dalam pengusahaan sumber daya perikanan di Laut Jawa. Armada pukat cincin berkembang pesat sejak tahun 1976 dan daerah penangkapan tersebar luas di perairan paparan Sunda, di antaranya Laut Jawa, Selat Makassar, Laut Cina Selatan, Selat Karimata, dan saat ini telah mencapai perairan Sulawesi. Tahun 1994 diindikasikan perkembangan daerah penangkapan ini telah mencapai maksimum. Tujuan dari penelitian ini adalah untuk mengemukakan perkembangan hasil tangkapan dan upaya ikan pelagis di Laut Jawa berdasarkan pada data berbasis hasil tangkapan pukat cincin yang mendarat di Pekalongan tahun 2002-2007. Hasil penelitian menunjukkan bahwa ikan layang (Decapterus spp.) tetap merupakan jenis utama atau dominan hampir di semua daerah penangkapan, yaitu $52 \%$ dari seluruh hasil tangkapan. Hasil tersebut tidak berbeda dengan hasil pada tahun 1985-1992. Jumlah trip mengalami penurunan yang cukup signifikan pada bulan Nopember 2005 karena adanya kenaikan harga bahan bakar minyak. Penurunan jumlah trip ini diikuti dengan meningkatnya jumiah hari di laut menjadi sekitar 2 bulan. Laju tangkap terus mengalami penurunan dari $1.000,7 \mathrm{~kg}$ per hari pada tahun 2004, menjadi $409 \mathrm{~kg}$ per hari pada tahun 2007. Ratarata laju tangkap tersebut jauh lebih kecil jika dibandingkan pada tahun 1992-1996 yang mencapai $2.387 \mathrm{~kg}$ per hari. Di antara 7 daerah penangkapan di perairan Laut Jawa dan Selat Makassar, laju tangkap lebih tinggi dijumpai di perairan sekitar Kepulauan Kangean, yaitu sekitar $950 \mathrm{~kg}$ per hari.

KATAKUNCl: pukat cincin, pelagis kecil, daerah penangkapan, jumlah trip, laju tangkap

\section{ABSTRACT: Trend of small pelagic fish catch in the Java Sea. By: Achmad Zamroni and Suwarso}

Purse seine is the main fishing gear of small pelagic fisheries and the most important gear for fisheries resources exploitation in Java sea. Since 1976, purse seine has spread out quickly and the seiners were able to extend their exploitation area outside the Java sea. In 1994, it indicated that fishing area has reached the maximum point. The purpose of this study is to explain catch development of pelagic fish in the Java sea based on catch data of purse seine that landed in Pekalongan from 2002-2007. The results show that scads (Decapterus spp.) species still provided the main target of the exploitation and represents $52 \%$ of the total catch. This condition was found similarly in $1985-$ 1992. The fishing trip of vessel decreased significantly in November 2005 due to the increase of fue! price. The day at sea increased up to 2 months. Catch per unit of effort also decreased from $1,000.7 \mathrm{~kg}$ per day in 2004 becoming $409 \mathrm{~kg}$ per day in 2007 . This catch per unit of effort was significantily smaller than the results in 1992-1996 that reached 2,387 kg per day. From the seven fishing areas of waters around the Kangean archipelago provided the highest catch per unit of effort, of about $950 \mathrm{~kg}$ per day.

\section{KEYWORDS: $\quad$ purse seine, small pelagic, fishing ground, number of trip, catch rate}

\section{PENDAHULUAN}

Pukat cincin merupakan alat tangkap utama untuk perikanan pelagis kecil serta mempunyai peranan penting di dalam pengusahaan sumber daya perikanan di Laut Jawa. Armada pukat cincin berkembang pesat sejak tahun 1976 dan daerah penangkapan tersebar luas di perairan paparan Sunda, di antaranya Laut Jawa, Selat Makassar, Laut Cina Selatan, Selat Karimata, dan saat ini telah mencapai perairan Sulawesi. Peranan armada pukat cincin menjadi semakin penting karena dalam perkembangannya memungkinkan menuju pada tingkat eksploitasi yang berlebihan, sehingga dapat membahayakan stok ikan yang ada. Tahun 1994 diindikasikan bahwa perkembangan daerah penangkapan ini telah mencapai maksimum (Portier \& Sadhotomo, 1995).

Adanya kejadian atau peristiwa yang menyangkut perubahan politik, sosial, dan ekonomi di antaranya krisis ekonomi dan kenaikan harga bahan bakar minyak dapat berpengaruh terhadap kegiatan eksploitasi armada perikanan terutama pukat cincin. $\mathrm{Hal}$ tersebut menjadikan para nelayan melakukan 
suatu antisipasi dan penyesuaian dalam hal penangkapan ikan. Tujuan dari penelitian ini adalah untuk mengemukakan perkembangan hasil tangkapan dan upaya ikan pelagis di Laut Jawa berdasarkan pada data basis hasil tangkapan pukat cincin yang mendarat di Pekalongan tahun 2002-2007 dengan harapan dapat memberikan masukkan terhadap studi yang lebih lanjut untuk pengkajian stok.

\section{BAHAN DAN METODE}

Penelitian ini didasarkan pada data basis hasil tangkapan kapal pukat cincin yang mendarat di Pelabuhan Perikanan Nusantara Pekalongan. Data yang diambil selama 5 tahun, yaitu mulai dari tahun 2002-2007. Dalam analisis data dipisahkan berdasarkan pada keadaan musim dan daerah penangkapan. Secara garis besar, daerah penangkapan dikelompokkan menjadi 7 perairan, yaitu A. Laut Jawa, B. Selat Makassar, C. Kepulauan Kangean, Danau Selat Karimata, E. Laut Cina Selatan, F. perairan Sulawesi, dan G. Iain-lain. Data operasional kapal yang meliputi lama di laut dan daerah penangkapan diperoleh wawancara dari nakhoda kapal dan data keluar-masuk kapal serta data monitoring harian pelabuhan. Sedangkan untuk musim secara umum dibagi menjadi 4 , yaitu terdiri atas 1) musim barat (bulan Desember-Pebruari), 2) musim peralihan 1 (bulan Maret-Mei), 3) musim timur (bulan JuniAgustus), dan 4) musim peralihan 2 (bulan September-Nopember).

\section{HASIL. DAN BAHASAN}

\section{Kompsisi Hasil Tangkapan}

Berdasarkan pada hasil tangkapan armada pukat cincin yang didaratkan pada Pelabuhan Perikanan Nusantara Pekalongan dari tahun 2002-2007 menunjukkan bahwa ikan layang (Decapterus russelli dan D. macrosoma) tetap merupakan spesies yang dominan hampir di semua daerah penangkapan (Gambar 1), mencapai $42-58 \%$ dari total hasil tangkapan (rata-rata 52\% dari total hasil tangkapan). Hasil tersebut tidak berbeda dengan hasil pada tahun 1985-1992 yang juga didominansi oleh spesies ikan layang (Portier \& Sadhotomo, 1995). Widodo (1990) juga mengatakan dalam penelitiannya yang dilakukan pada bulan Maret-Desember 1986, bahwa kelompok jenis ikan layang menduduki peringkat teratas, yaitu sekitar $49 \%$ dari seluruh jenis ikan yang tertangkap. Hal serupa juga dikatakan oleh Sadhotomo et al. (1986) bahwa jenis ikan layang untuk setiap daerah penangkapan tetap merupakan bagian terbesar dari keseluruhan hasil tangkapan pukat cincin. Sedangkan komposisi untuk spesies ikan pelagis kecil yang lain, di antaranya ikan banyar (Rastrelliger kanagurta), bentong (Selar crumenophthalmus), siro (Amblygaster sirm), jui (Sardinella spp.), dan lain-lain sekitar $0-15 \%$ dari total hasil tangkapan. Masingmasing jenis ikan mempunyai variasi persentase hasil tangkapan tahunan (Gambar 2).

Spesies ikan pelagis kecil yang tertangkap oleh armada pukat cincin terdiri atas 5 jenis spesies utama, yaitu Rastrelliger kanagurta, Selar crumenophthalmus, Decapterus spp., Amblygaster sirm, dan Sardinella sp. Rata-rata hasil tangkapan untuk ikan layang di perairan Laut Cina Selatan lebih tinggi dibandingkan dengan perairan lain (Gambar 3). Menurut Sudjastani \& Amin (1978), pada perairan di sekitar Pulau Midai (Laut Cina Selatan) terdapat sediaan ikan layang yang cukup besar. Sedangkan Atmadja (2006) mengatakan bahwa dominannya hasil tangkapan suatu spesies ikan dikarenakan nelayan telah melakukan seleksi spesies pada ikan-ikan tertentu (bernilai ekonomis tinggi), seperti ikan layang dan banyar. Hal yang sama juga terjadi pada spesies

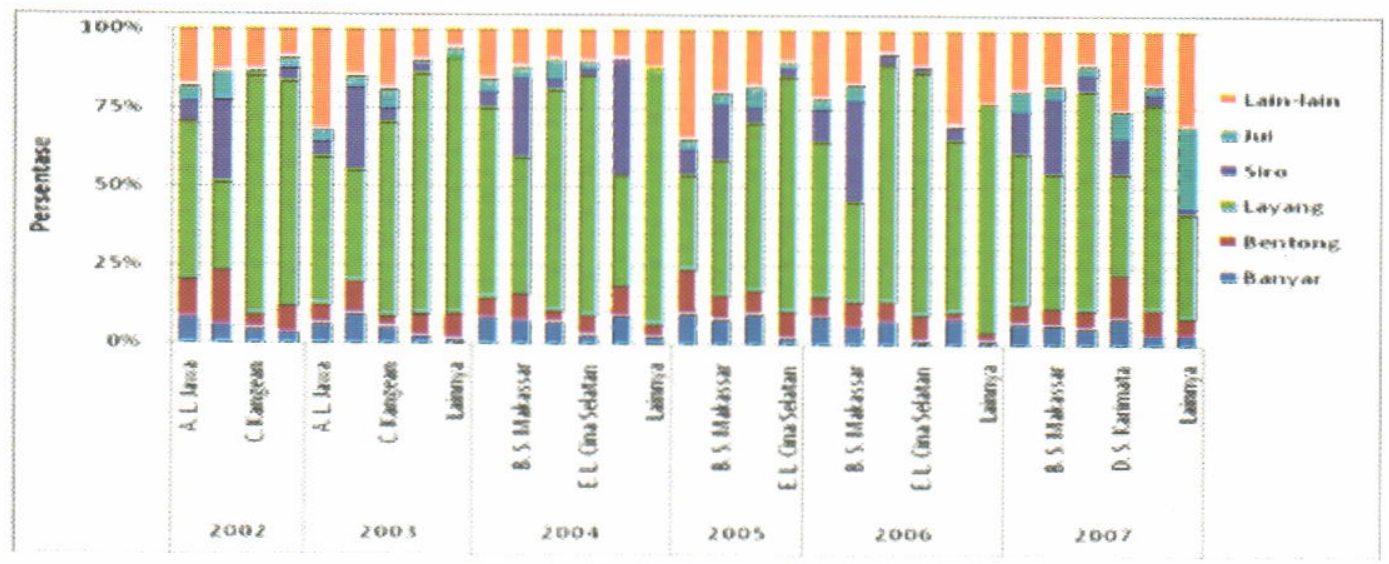

Gambar 1. Komposisi hasil tangkapan menurut daerah penangkapan.

Figure 1. Catch composition according to the fishing area. 


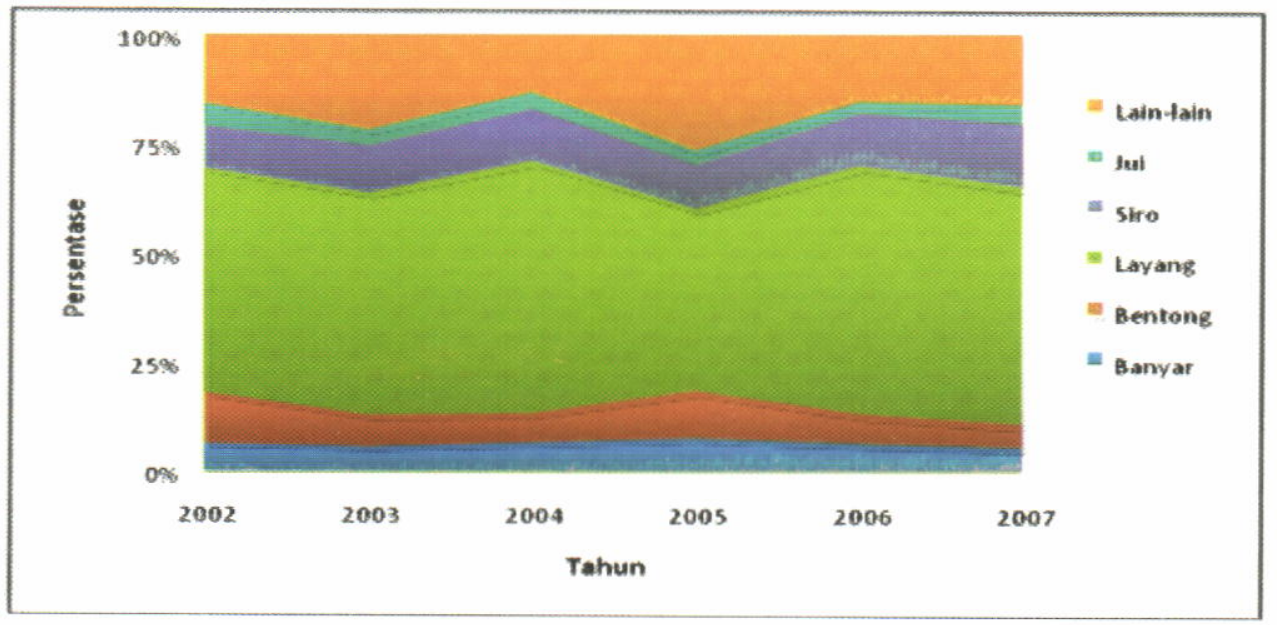

Gambar 2. Persentase hasil tangkapan tahunan armada pukat cincin di Pekalongan.

Figure 2. Annual percentage catch of purse seine in Pekalongan.

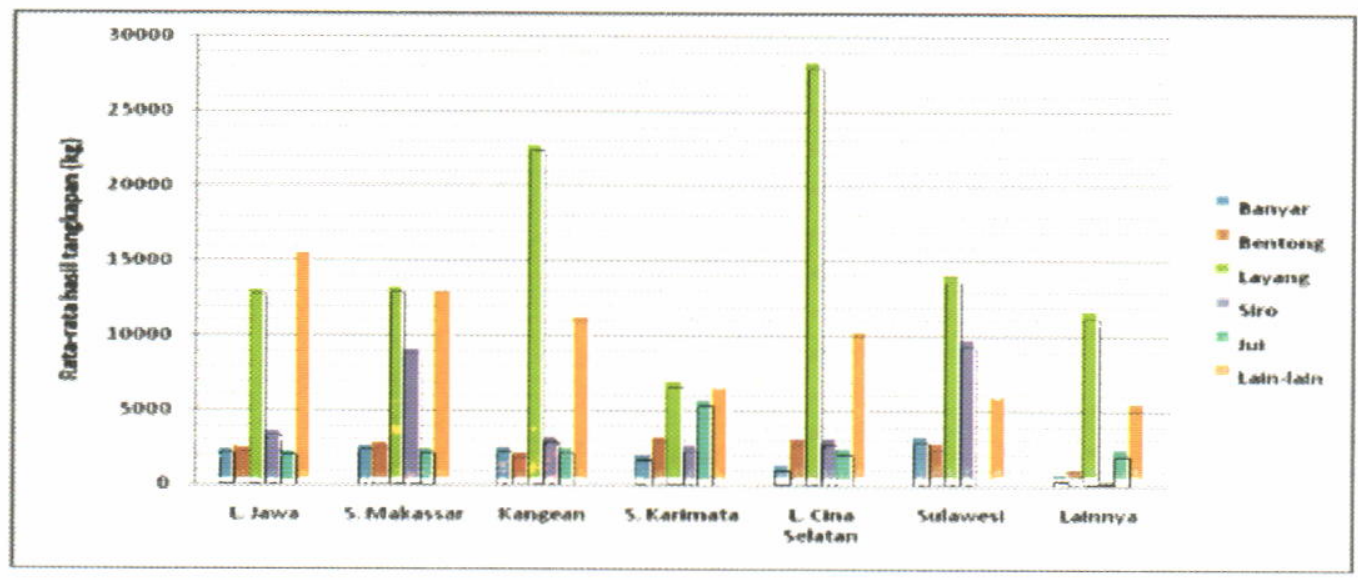

Gambar 3. Rata-rata hasil tangkapan pelagis kecil menurut daerah penangkapan.

Figure 3. Average catch of small pelagic fish according to the fishing area.

ikan ayam-ayaman (Alutera monoceros) sejak tahun 2002 mempunyai hasil tangkapan yang meningkat dikarenakan ikan ini mempunyai nilai ekonomis setelah ada permintaan dari Korea.

\section{Hasil, Upaya, dan Laju Tangkap}

Menurut Atmadja (2006), kapal pukat cincin yang berpangkalan di Pekalongan keluar dari pelabuhan terjadi setiap hari dengan puncak jumlah kapal terjadi pada tanggal 24 kalender tiap bulan. Perkembangan jumlah trip dari periode bulan Sepetember 2003-2007 menunjukkan bahwa jumlah trip cenderung berfluktuasi pada setiap tahunnya (Gambar 4). Untuk data trip kapal tahun 2002-2003 yang diperoleh kurang atau belum lengkap. Pada akhir tahun 2003 atau tepatnya pada bulan Oktober 2003 terjadi peningkatan jumlah trip yang cukup tajam. Hal ini diduga bahwa peningkatan tersebut karena mulai pulihnya armada pukat cincin dari krisis ekonomi sejak tahun 1998. Pada bulan Nopember 2005 terjadi penurunan jumlah trip yang cukup drastis, dari 198 trip menjadi 30 trip per bulan. Penurunan ini dikarenakan pada minggu pertama bulan Oktober 2005 terjadi kenaikan harga bahan bakar minyak. Fluktuasi jumlah trip tersebut berpengaruh juga terhadap jumlah hasil tangkapan ikan tahunan. Hasil tangkapan mulai meningkat pada tahun 2003 dan mencapai puncaknya pada tahun 2004, yaitu 54.000 ton. Penurunan jumlah trip yang terjadi mulai bulan Nopember 2005 tersebut berbanding terbalik dengan lama hari di laut. Jumlah hari di laut cenderung meningkat mulai bulan Januari 2006 dari 46 hari per trip menjadi 61 hari ( 2 bulan) per trip (Gambar 5). Hal ini terjadi atau dilakukan oleh nelayan untuk menyiasati terhadap naik atau mahalnya harga bahan bakar minyak, yaitu dengan mengurangi trip dan menambah hari di laut. Pada bulan Januari-Mei 2003 data mengenai rata-rata lama 
hari di laut tidak diperoleh, sehingga grafik pada Gambar 5 terputus. Portier \& Sadhotomo (1995) mengatakan bahwa jumlah trip sejak tahun 1979-1992 terus mengalami penurunan. Hal tersebut berlawanan dengan lama hari di laut yang terus meningkat sejak tahun 1980.

Laju tangkap rata-rata perikanan pukat cincin yang didaratkan di Pekalongan dari tahun 2002-2007 mempunyai kecenderungan mengalami penurunan. Hasil yang lebih tinggi pada periode tersebut terjadi pada tahun 2004, yaitu $1.000,7 \mathrm{~kg}$ per hari. Penurunan yang cukup signifikan terjadi pada tahun 2005, yaitu dari $1.000,7 \mathrm{~kg}$ per hari menjadi $646,6 \mathrm{~kg}$ per hari dan pada tahun 2007 menjadi 409 kg per hari (Gambar 6). Penurunan nilai laju tangkap tersebut selain karena adanya kenaikan harga bahan bakar minyak pada tahun 2005 juga karena para nelayan memperpanjang lama hari di laut. Menurut Sadhotomo et al. (1986), semakin lama kapal berada di laut, laju tangkapannya cenderung menurun. Nilai laju tangkap pada periode tahun 2002-2007 jauh lebih rendah jika dibandingkan dengan laju tangkap pada periode tahun 1992-1996 yang mempunyai nilai laju tangkap mencapai 2.387 kg per hari.

Fluktuasi laju tangkap rata-rata berdasarkan pada musim dapat terlihat bahwa pada musim peralihan 2 dan awal musim barat mempunyai nilai laju tangkap yang cenderung lebih tinggi jika dibandingkan dengan musim-musim yang lain (Gambar 7). Hasil ini tidak berbeda dengan penelitian yang dilakukan oleh Atmadja et al. (1986). Menurut Atmadja et al. (1986), spesies ikan layang dan banyar mencapai puncak hasil tangkapan pada musim peralihan 2 dan untuk spesies ikan siro mencapai puncak pada musim barat. Pada penelitian ini spesies yang dominan tertangkap adalah ikan layang, siro, dan banyar, sehingga laju tangkap yang lebih tinggi terjadi pada musim peralihan 2 dan awal musim barat. Terjadinya fluktuasi laju tangkap dimungkinkan karena adanya perubahan musim yang menyebabkan perubahan kondisi lingkungan. Perubahan kondisi lingkungan mempengaruhi beberapa jenis ikan tertentu untuk melakukan ruaya seperti ikan layang dan banyar yang beruaya mengikuti perubahan salinitas air (Atmadja et al., 1986).

Dalam penelitian ini (tahun 2002-2007) terbagi 7 daerah penangkapan kapal pukat cincin Pekalongan. Di antara 7 daerah penangkapan di perairan Laut Jawa dan Selat Makassar, laju tangkap lebih tinggi dijumpai di perairan sekitar Kepulauan Kangean, yaitu ratarata sekitar $950 \mathrm{~kg}$ per hari. Perairan di sekitar Kepulauan Kangean mempunyai nilai rata-rata laju tangkap yang lebih tinggi hampir setiap tahunnya (Gambar 8). Pada penelitian yang dilakukan oleh Atmadja et al. (1986) mengatakan bahwa di setiap musim hasil tangkapan terbesar terdapat di perairan sekitar Masalembo dan Matasiri.

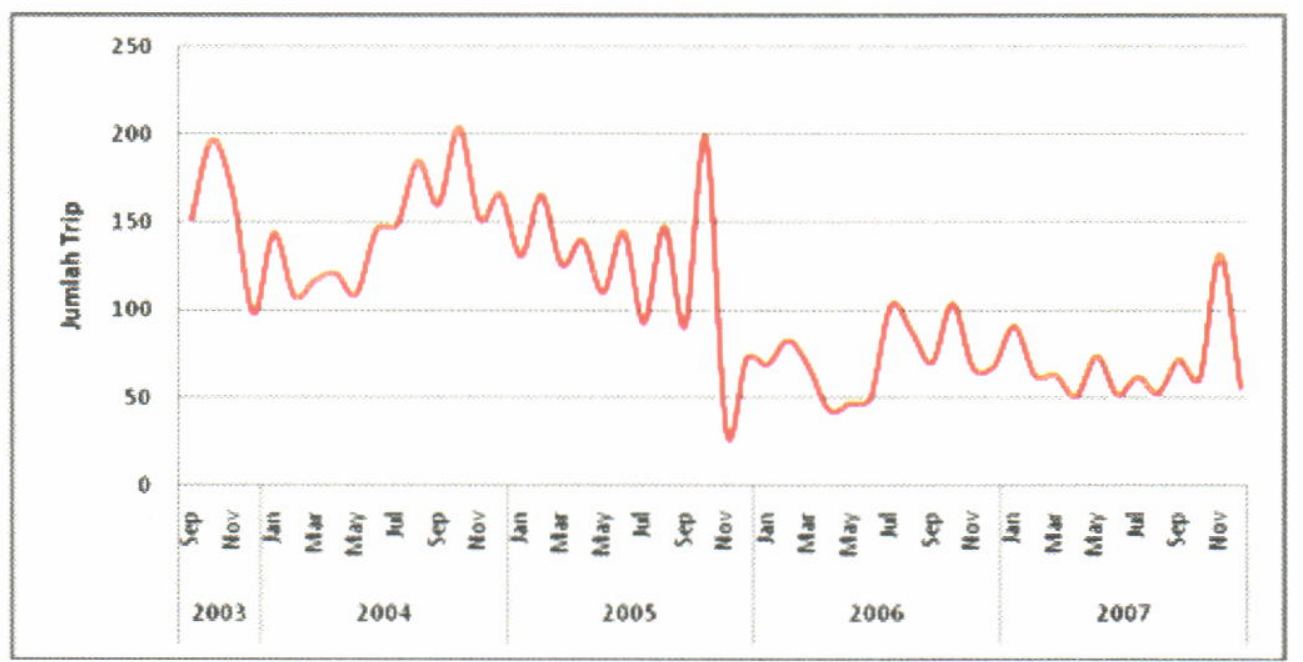

Gambar 4. Jumlah trip bulanan kapal pukat cincin di Pekalongan.

Figure 4. Monthly trip of purse seine vessels in Pekalongan. 
Perkembangan Hasil Tangkapan Ikan Pelagis Kecil di Sekitar Laut Jawa (Zamroni, A. \& Suwarso)

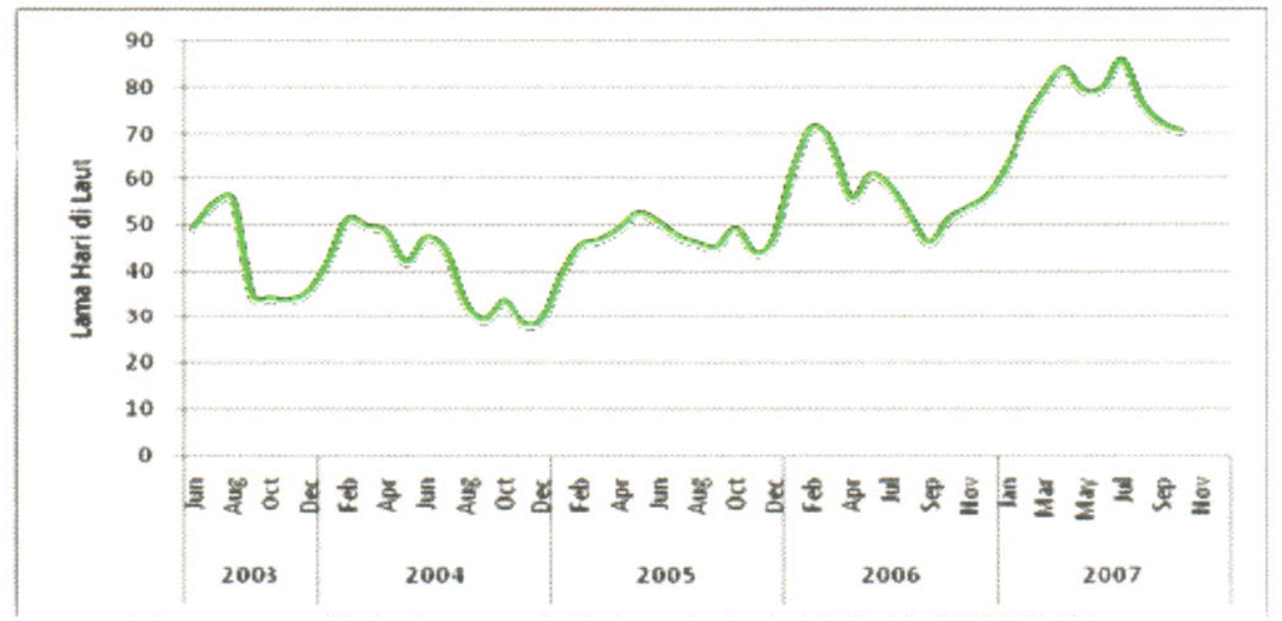

Gambar 5. Jumlah rata-rata lama hari di laut bulanan kapal pukat cincin di Pekalongan. Figure 5. Average of day at sea of purse seine vessels in Pekalongan.

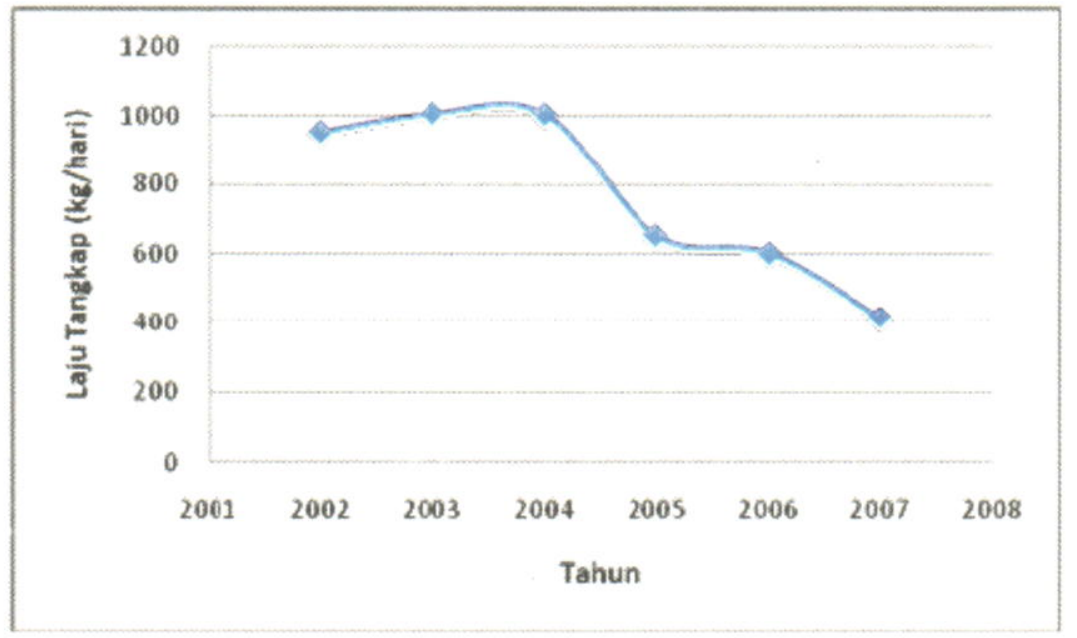

Gambar 6. Laju tangkap rata-rata tahunan kapal pukat cincin di Pekalongan.

Figure 6. Average catch per unit of effort of purse seine vessels in Pekalongan.

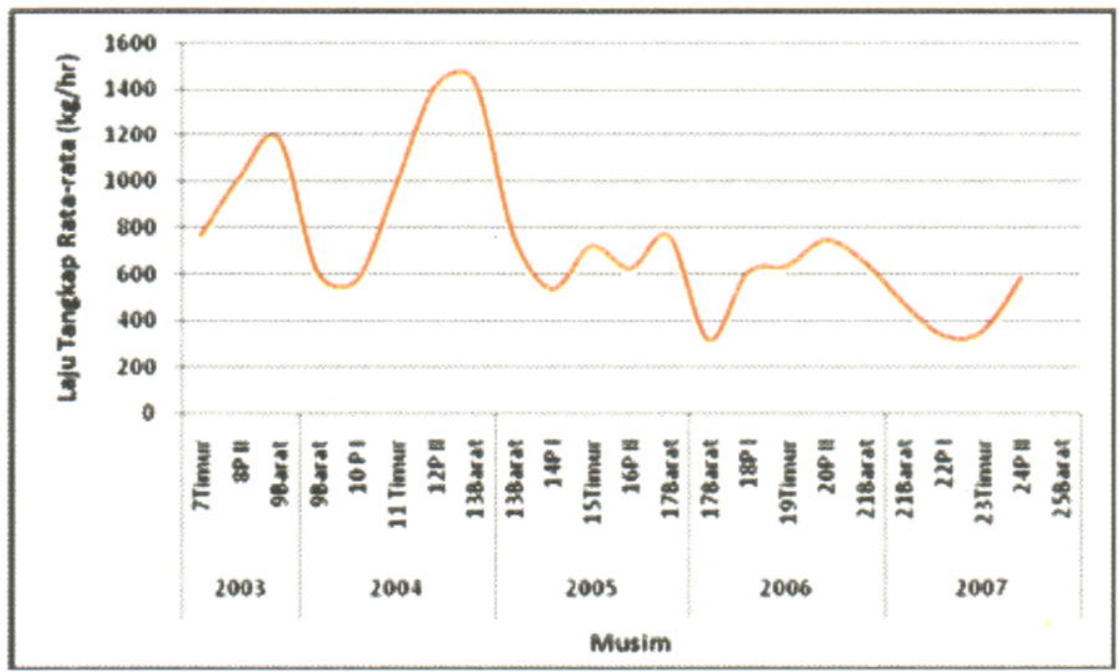

Gambar 7. Fluktuasi laju tangkap rata-rata kapal pukat cincin di Pekalongan berdasarkan pada musim. Figure 7. Fluctuation of average catch per unit of effort purse seine vessels in Pekalongan by season. 


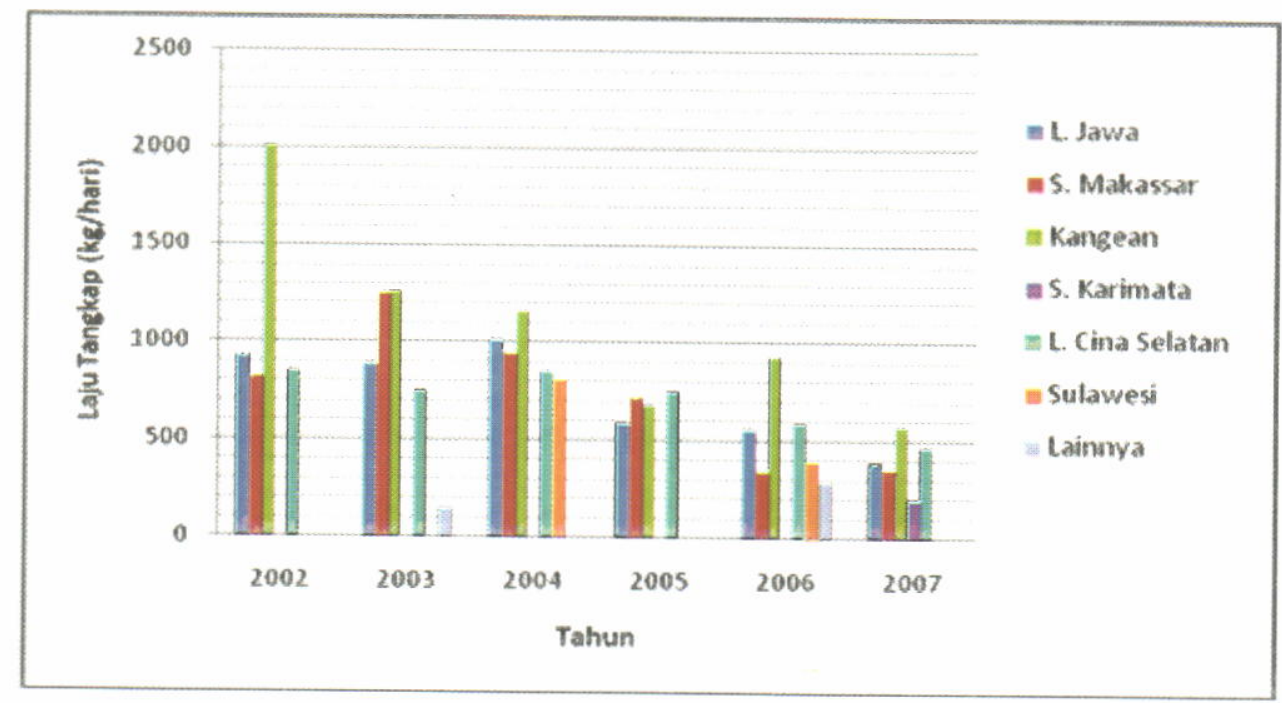

Gambar 8. Laju tangkap rata-rata tahunan menurut daerah penangkapan.

Figure 8. Annual average catch per unit of effort according to the fishing area.

\section{KESIMPULAN}

Beberapa kesimpulan yang dapat diambil dari penelitian ini adalah bahwa ikan layang tetap merupakan jenis utama atau dominan hampir di semua daerah penangkapan, yaitu rata-rata $52 \%$ dari seluruh hasil tangkapan. Pada periode bulan September 2003-2007 terjadi penurunan jumlah trip, penurunan cukup signifikan terjadi pada bulan Nopember 2005 karena kenaikan harga bahan bakar minyak. Jumlah lama hari di laut mengalami peningkatan dari 46 hari menjadi 61 hari ( 2 bulan) per trip. Laju tangkap terus mengalami penurunan dari $1.000,7 \mathrm{~kg}$ per hari pada tahun 2004 menjadi $409 \mathrm{~kg}$ per hari pada tahun 2007. Di antara 7 daerah penangkapan di perairan Laut Jawa dan Selat Makassar, laju tangkap lebih tinggi dijumpai di perairan sekitar Kepulauan Kangean, yaitu sekitar 950 kg per hari.

\section{PERSANTUNAN}

Tulisan ini merupakan kontribusi dari kegiatan riset perkembangan pukat cincin mini setelah kolapsnya pukat cincin besar di bagian timur pantai utara Jawa, T. A. 2007, di Balai Riset Perikanan Laut, Muara BaruJakarta.

\section{DAFTAR PUSTAKA}

Atmadja, S. B., Suwarso, \& S. Nurhakim. 1986. Hasil tangkapan pukat cincin menurut musim dan daerah penangkapan di Laut Jawa. Jurnal Penelitian Perikanan Laut. 34: p. 57-68.
Atmadja, S. B. 2006. Selektivitas pukat cincin dan seleksi manusia pada ikan pelagis kecil di Laut Jawa. Dalam Perikanan Pukat Cincin dan Sumber Daya Ikan Pelagis Kecil di Bagian Selatan Paparan Sunda. Balai Riset Perikanan Laut. p 50-56.

Atmadja, S. B. 2006. Eksploitasi pukat cincin Pekalongan di perairan Laut Cina Selatan. Dalam Perikanan Pukat Cincin dan Sumber Daya Ikan Pelagis Kecil di Bagian Selatan Paparan Sunda. Balai Riset Perikanan Laut. p. 57-64.

Portier, M. \& B. Sadhotomo. 1995. Exploitation of the large and medium seiners fisheries. In Biodynex (Biology, Dynamics, Exploitation) of the Small Pelagic Fishes in the Java Sea. Potier, M. \& S. Nurhakim (Ed.). p. 196-214.

Sadhotomo, B., S. Nurhakim, \& S. B. Atmaja. 1986. Perkembangan komposisi hasil tangkapan dan laju tangkap pukat cincin di Laut Jawa. Jurnal Penelitian Perikanan Laut. 35: p. 101-109.

Sudjastani, T. \& E. M. Amin. 1978. Kemungkinan pengembangan dan modernisasi perikanan skala kecil atau perikanan rakyat di Laut Cina Selatan yang termasuk kawasan Kabupaten Kepulauan Riau. Simposium Modernisasi Perikanan Rakyat. Lembaga Penelitian Perikanan Laut. Penelitian dan Pengembangan Pertanian. $26 \mathrm{pp}$.

Widodo, J. 1990. Penyebaran kelimpahan, musim, dan daerah penangkapan ikan pelagis pantai di Laut Jawa. Jurnal Penelitian dan Pengembangan Pertanian. IX (1). 